\title{
Venture Financing in Russia, Exits and Initial Public Offering Performance
}

\author{
Oksana A. Karpenko
}

\begin{abstract}
Modern science and practice draw attention to the many issues related to the financial and resource support transition to innovative development of economic systems at all levels. The venture is one of the ways of financing of innovation. Market venture investments in Russia are currently at the stage of rapid growth and development. There are many different ways of exit, for example by initial public offering(IPO) or transactions of merge and acquisition (M\&A).
\end{abstract}

Index Terms - Investments in innovation, venture capital, venture capital funds, venture financing.

\section{INTRODUCTION}

Modernization and transformation of economic conditions and processes on the basis of innovative transformations is the cornerstone of successful development. The new economic trend of development is based on the innovative paradigm meaning development of new technologies, carrying out scientific researches and an entry into the global world markets. The resource economy which was until recently dominating in Russia gives way to the economy of knowledge based on innovations and new technologies.

One of the best types of financing within innovative economy is the venture financing representing capital investments in development of the new enterprise, company or the project which is unique and interesting not having analogues. For investors it is chance to get huge profit, thus risking to lose all investments, for the enterprise opportunity or to increase the value of business and to provide growth of the efficiency [1].

Main goal of venture investment is an opportunity for investors in the future to sell the share at the price considerably exceeding the buying price that allows the venture capitalist to pay back investments and to get the desired profit [2].

Nowadays there are many different ways of sale of the shares in firm: initial public offering at stock exchange, acquisition, secondary sale, write-off and the return repayment, sale to internal and external management. The most profitable of them is the initial public offering (IPO) or transactions of merge and acquisition (M\&A). According to the opinion of managing directors of funds more, than in half of cases exits give profit, however the lion's share of investors originally expected considerably bigger income, than they managed to receive during an exit [3].

The important role in search of the potential buyer of the

Manuscript received July 14, 2017; revised October 10, 2017.

Oksana A. Karpenko is with the Russian University of Peoples' Friendship, Russia (e-mail: karpenox@list.ru). company is played by financial consultants, the staff of investment banks who are engaged in long process of preparation of the company for sale. They are engaged in search of the best ways of an exit from business suitable both the investor, and management of the company [4]. Many prominent scientists are looking for the different ways of funding innovative activities in venture companies and in small and medium enterprises [5]

Harel, R.,Kaufmann, D. [6] studied the funding difficulties of innovative small and medium enterprise in traditional sectors and asked whether current conditions represent a financing market failure and explored the financial tools available in Israel and their relevancy by conducting in-depth interviews with different key figures in the financial industry. These included managers at venture capital funds, banks, private equity funds, mezzanine funds, as well as officials from the public sector. The study proposed a funding scheme that addresses the special needs of these companies.

Hua, X. ,Wang, Y., Wang, M. [7] examined the impacts of venture capital on performance and innovation of China's small- and medium-sized enterprises. They found that venture capital financing not only spurred innovation in the Chinese market, but also exhibited significantly positive impact on financial performance. Empirical evidence revealed that syndication of venture capital investment as well as the reputation of venture capitalists helped to create value for venture firms.

Brander, J. A., Amit, R.,Antweiler, [8] W. explored the syndication and tested two possible reasons for syndication: project selection, as an additional venture capitalist provides an informative second opinion; and complementary management skills of additional venture capitalists. Their empirical analysis, using Canadian data, found that syndicated investments have higher returns, favoring the value-added interpretation.

Amit, R. Brander, J., Zott, C. [9] investigated the role of venture capitalists. Their empirical examination of Canadian venture capital shows there are significant industry effects in the data, with venture capitalists having disproportionate representation in industries that are thought to have high levels of informational asymmetry.

Casamatta, C. [10] analyzed the joint provision of effort by an entrepreneur and by an advisor to improve the productivity of an investment project. Without moral hazard, it is optimal that both exert effort. This explained why investors liked venture capitalists are value enhancing. The level of outside financing determined whether common stocks or convertible bonds should be issued in response to incentives.

One of the main problems of venture financing is to find 
effective way of an exit from the company is the exit by Initial public offering (IPO). In the countries with the developed and liquid stock market it the most popular way of financing.

This form of an exit assumes receiving money with an essential award and allows to provide liquidity of the share capital. Thus the companies entering the public market have to correspond to a number of requirements, large volume of operations and the sufficient size of the company [10]. The entry into the public market require the ability to open financial statements. In the Russian Federation there are legislative features speaking about need of carrying out IPO at first in Russia, and already then a conclusion of actions to the international markets by means of ADR and GDR [9].

Initial Public Offering of the Russian companies at the American exchanges happens infrequently, and it guards investors. But opportunity to take Internet search engine shares around $\$ 20$ for an action looks attractive: shares of Google are traded for $\$ 522$, the Chinese Baidu - for $\$ 163$.

Procedure of primary public placement includes some stages:

1) Making decision on placement of issue securities;

2) Approval of the decision on issue (additional release) of issue securities;

3) State registration of issue (additional release) of issue securities;

4) Offering of issue securities;

5) State registration of the report on results of additional production of issue valuable papers/ direction of the notice of results of issue of securities (additional release).

Each stage of procedure of IPO demands disclosure of information in the order established by regulations of federal executive authority on securities market. Public placement of securities demands considerable time for preparation, for it can leave from 3-4 months to 1 year depending on readiness of the issuer to an entry into the public market.

In case the venture company possesses the small capital, at placement of securities its inclusion is possible:

1) In one of quoted lists "B" or "I";

2) In the section of the list of the securities allowed to the auction without listing procedure passing.

The venture company has the right to choose the option depending on compliance of actions to the certain requirements imposed to issuers of securities. In that a case if securities of firm enter the quoted list "I", it will allow to attract new category of the investors inclined to the increased risk, - the natural and legal entities who signed the corresponding declaration on risks, and also specialized collective investments (the qualified clients).

The venture company can independently choose IPO venue. Today there is a number of advantages when carrying out IPO in domestic market:

1) Reduction of the period of preparation and placement of securities. So, the period of preparation and carrying out placement in domestic market makes from 4-6 to 10 months, in Great Britain - from 7-8 to 18 months, in the USA - from 10-11 till 24 months;

2) Lower expenses on placement, expenses make from 5 to $10 \%$ of the raised funds that is $1,5-2$ times less, than in foreign markets;
3) Softer requirements to a set of documents at placement of securities and to the volume of disclosed information;

4) An absence of currency risk at acquisition of securities the majority of categories of foreign investors;

5) Excess of domestic demand for investment tools over the offer;

6) Recognition of a brand in the Russian market.

It is necessary to notice that the available practice of pricing on the Russian securities market gives great opportunities for capitalization growth, increasing thereby status of securities of new issuers in the opinion of investors;

Certainly, IPO can use only a small amount of venture projects as entry into the market of securities is possible only for the highly profitable companies, the activity providing transparency. After the IPO company has to provide interaction with investors: new and potential shareholders that involves additional expenses.

The positive moment of carrying out IPO is opportunity to attract credit resources at the time of placement and after it as IPO helps business development, can raise the status of the company and its investment appeal. All pluses and minuses of an exit by means of carrying out IPO are presented in Table I.

TABLE I: THE PLUSES AND THE MINUSES OF CARRYING OUT IPO FOR THE VENTURE COMPANIES

\begin{tabular}{|c|c|c|}
\hline & Advantages of IPO & Shortcomings of IPO \\
\hline 1. & $\begin{array}{l}\text { Constant liquidity of actions } \\
\text { which is supported by portfolio } \\
\text { investors }\end{array}$ & $\begin{array}{l}\text { Preparation and carrying out } \\
\text { IPO represents difficult and } \\
\text { expensive process, both with } \\
\text { financial, and from the } \\
\text { operational point of view. }\end{array}$ \\
\hline 2. & $\begin{array}{l}\text { Issue of securities is one of } \\
\text { constant sources of additional } \\
\text { financing. It allows to form } \\
\text { capitalization and to raise funds } \\
\text { in the form of the share and debt } \\
\text { capital in stock market for } \\
\text { further business development }\end{array}$ & $\begin{array}{l}\text { Expensive payment for } \\
\text { services of organizers (the } \\
\text { underwriter, auditors, legal } \\
\text { advisers, the exchanges) } \\
\text { which makes } 5-10 \% \text { of the } \\
\text { raised funds. }\end{array}$ \\
\hline 3. & $\begin{array}{l}\text { The status of the company in the } \\
\text { person of potential investors } \\
\text { raises. The company starts } \\
\text { enjoying confidence at suppliers, } \\
\text { banks, buyers }\end{array}$ & $\begin{array}{l}\text { Long process of preparation } \\
\text { for IPO It can take } 0,5-1,5 \\
\text { years. }\end{array}$ \\
\hline 4. & Recognition of a brand. & $\begin{array}{l}\text { Obligatory disclosure of the } \\
\text { reporting before shareholders, } \\
\text { increase in volume of the } \\
\text { obligatory reporting before } \\
\text { government }\end{array}$ \\
\hline 5. & $\begin{array}{l}\text { Opportunity to involve the best } \\
\text { management. }\end{array}$ & $\begin{array}{l}\text { At adoption of administrative } \\
\text { decisions the management of } \\
\text { the company will have to take } \\
\text { opinion of investment } \\
\text { community into account, } \\
\text { predict influence of the made } \\
\text { decisions on share price. }\end{array}$ \\
\hline
\end{tabular}

The choice of a way of share sale and obtaining the income causes concern of the venture investor throughout the entire period of investment in view of the fact that profitability of invested funds depends on a successful exit. Very often important decision on a way and time of sale of a share is accepted in advance, at the time of implementation of investments. Meanwhile, in Russia there are all necessary conditions (the legislation and infrastructure) which allow 
the company to carry out a successful exit from venture projects by carrying out IPO.

The number of known exits in the Russian Federation remains small and makes about 10-20 transactions every year. The reason of it is brief experience of investors, not really extensive network of professional contacts and limitation of domestic market. The international markets for the domestic venture companies become more and more inaccessible. Nevertheless, the whole series of the successful exits which had positive impact on the market took place in recent years. Within the last 3 years six Russian companies of sector of high technologies carried out the international IPO. Some Russian companies entered domestic market. The total volume of the raised funds made 1 bln. dollars. The most noticeable exits of venture investors through IPO in 2010-2013 are presented in Table II.

TABLE II: THE EXITS OF VENTURE INVESTORS THROUGH IPO IN 2010-

\begin{tabular}{|l|l|l|l|}
\hline Company & Segment & $\begin{array}{l}\text { The Volume of } \\
\text { Transactions }\end{array}$ & $\begin{array}{l}\text { Date of an } \\
\text { exit }\end{array}$ \\
\hline Yandex & Internet & 1435 & May 2011 \\
\hline $\begin{array}{l}\text { Tinkoff } \\
\text { credit } \\
\text { systems }\end{array}$ & $\begin{array}{l}\text { Information } \\
\text { technologies }\end{array}$ & 1087 & October 2013 \\
\hline $\begin{array}{l}\text { Mail.ru } \\
\text { Group }\end{array}$ & Internet & 912 & $\begin{array}{l}\text { November } \\
2010\end{array}$ \\
\hline EPAM & $\begin{array}{l}\text { Information } \\
\text { technologies and }\end{array}$ & 490 & February2012 \\
\hline QIWI & $\begin{array}{l}\text { Business and } \\
\text { financial services }\end{array}$ & 244 & May 2013 \\
\hline Luxoft & $\begin{array}{l}\text { Information } \\
\text { technologies }\end{array}$ & 80 & June 2013 \\
\hline
\end{tabular}

Источник: Е\&Y.

The exit to IPO of two large companies - Yandex and Tinkoff-credit systems is especially interesting. Yandex gained $1435 \mathrm{mln}$. dollars which the company directed on the all-corporate purposes from IPO, including investments into technological infrastructure, including acquisition server and data-centres, and also on absorption and investments into technologies, experts or the companies, whose profile is similar to the operations "Yandex". Shares of the company considerably grew in price for the first year of the auction that gives the grounds to speak about the high potential of actions of "Yandex" in the short term.

The Tinkoff-credit system company which is connected with high technologies attracted in one year and five months prior to IPO a final round of financing.

The exit by means of IPO is the perspective, but still infrequent way of an exit from investments, in view of high cost and a saturation of process, and also obligations of the company to provide publicity and openness after its carrying out. Investment banks will cooperate and help with an exit only to those companies which have capitalization about 200-250 million dollars.

The most widespread exit from the venture project abroad is sale to the strategic investor. Very often business "stake" is redeemed by means of use of options of "fetters" also even during the structuring the transaction and coordination of conditions.

In exchange for the right for the venture investor to sell a share to the strategic investor, issued by means of fetters options, the buyer receives the call option on repayment of this part of business. In the Russian Federation with absence of legislative regulation of options, such exits aren't carried out yet.

For the purpose of purchase of a share of the venture investor the businessman can use the cash flows generated by the company or obtain the credit subsequently refinanced due to issue of bonds. Also in case the company purpose more company buyer the exit of the company by use of actions (the transaction of LBO) is possible.

However in this situation the venture investor risks to receive part of money in the form of the long-term debt obligation. Its size depends on estimation of cost of the company and potential opportunities of managers. In recent years some exits of venture funds by means of carrying out transactions on merge and absorption (Table III) took place.

TABLE III: EXITS OF VENTURE INVESTORS BY TRANSACTIONS OF MERGE AND ACQUISITION

\begin{tabular}{|l|l|l|l|l|}
\hline Company & Segment & Buyer & $\begin{array}{l}\text { Volume of } \\
\text { transaction, } \\
\text { mln.dol. }\end{array}$ & Date \\
\hline Quik & $\begin{array}{l}\text { Social } \\
\text { networks }\end{array}$ & Skype & 121 & $\begin{array}{l}\text { June } \\
2011\end{array}$ \\
\hline B2B Center & $\begin{array}{l}\text { Business and } \\
\text { financial } \\
\text { services }\end{array}$ & $\begin{array}{l}\text { Elbrus } \\
\text { Capital }\end{array}$ & 52 & $\begin{array}{l}\text { April } \\
2013\end{array}$ \\
\hline Sapato & $\begin{array}{l}\text { Electronic } \\
\text { commerce }\end{array}$ & Ozon & 50 & $\begin{array}{l}\text { Februar } \\
\text { y } 2012\end{array}$ \\
\hline Sotmarket & $\begin{array}{l}\text { Electronic } \\
\text { commerce }\end{array}$ & IQ one & 50 & $\begin{array}{l}\text { August } \\
2012\end{array}$ \\
\hline Darberry & $\begin{array}{l}\text { Electronic } \\
\text { commerce }\end{array}$ & $\begin{array}{l}\text { Groupo } \\
\mathrm{n}\end{array}$ & 50 & $\begin{array}{l}\text { August } \\
2010\end{array}$ \\
\hline Slando & $\begin{array}{l}\text { Consumer } \\
\text { sector }\end{array}$ & Naspers & 50 & $\begin{array}{l}\text { October } \\
2011\end{array}$ \\
\hline Source: E\&Y & & & & \\
\hline
\end{tabular}

Source: E\&Y

Estimating data on exits, we can come to a conclusion that as a rule investors redeem the small projects created in the sphere of electronic commerce and a consumer sector.

Conclusion. Prompt development of the venture industry in recent years, developed internal and environment, successful "exits" from the companies testify that on condition of creation of the favourable environment the quantity of successful exits of the companies will increase repeatedly in the next 2-3 years. In case of preservation of economic instability the main way of an exit will be a sale to the company to the strategic investor.

In spite of the fact that the Russian Federation achieved considerable progress in creation of regulatory base for innovative activity and venture financing, protection of intellectual property rights and the antitrust law, lawenforcement practice remains so far at a low level. Formation of the Russian venture industry happens at slow speed. However in process of formation in the country of political and enterprise climate the industry of venture financing will gain the development.

\section{REFERENCES}

[1] H. Kraemer-Eis, F. Lang, and S. Gvetadze, European Small Business Finance Outlook, June2015.

[2] External evaluation of the pilot scheme CREA concerning support for venture capital companies financing SMEs in the seed and start-up phase final report, The Evaluation Partnership Limited 6 Cole Park Road Twickenham, Middlesex TW1 1HW United Kingdom, 30th January 2006 
[3] J. Napp and M. Minshall, "Corporate venture capital investments for enhancing innovation: Challenges and solutions," Research methodology management, vol. 54, no. 2, pp. 27-36, 2011.

[4] W.A. Sahlman, "The structure and governance of venture-capital organizations,"J ournal of Financial Economics, vol. 27, p. 473.

[5] Investment and Investment Finance in Europe, Investing in competitiveness, 2015.

[6] R.Harel and D. Kaufmann, "Financing innovative SMEs of traditional sectors: the supply side," EuroMed Journal of Business, vol. 11, Issue 1, pp. 84-100, 3 May 2016.

[7] X. Hua, Y. Wang, and M. Wang, "The innovation and performance impacts of venture capital investment on China's small- and mediumsized enterprises," China Economic Journal, vol. 9, Issue 2, pp. $167-$ 185, 3 May 2016.

[8] J. Brander, R. Amit, and R. Antweiler, "Venture-capital syndication: Improved venture selection vs. The value-added hypothesis," Journal of Economics and Management Strategy, vol. 11, Issue 3, pp. 423-452, September 2002.

[9] R. Amit, J. Brander, and C. Zott, "Why do venture capital firms exist? Theory and Canadian evidence," Journal of Business Venturing, vol. 13, Issue 6, pp. 441-466, November 1998.
[10] W. A. Sahlman, "The structure and governance of venture-capital organizations," Journal of Financial Economics, vol. 27, pp. 473, November 1998.

[11] C. Casamatta, "Financing and advising: Optimal financial contracts with venture capitalists," Journal of Finance, vol. 58, Issue 5, pp. 2059-2085, October 2003.

[12] R. Michaely and W. Shaw, "The choice of going public: Spin-offs vs," Carve-outs// Financial Management, vol. 24, pp. 5-21, Autumn 1995.

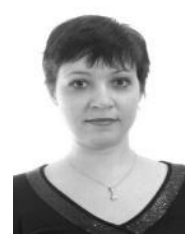

Oksana A. Karpenko is a $\mathrm{PhD}$ in economics, an associate professor of the chair "Finance and credit" of Economics department, Russian University of Peoples' Friendship, Russia.

Her research area of scientific interests are in finance, venture financing, investments. 